\title{
Biochemical properties of a novel thermostable and highly xylose-tolerant $\beta$-xylosidase/ $\alpha$-arabinosidase from Thermotoga thermarum
}

Hao Shi ${ }^{1,2 \dagger}$, Xun $\mathrm{Li}^{1,2 \dagger}$, Huaxiang Gu ${ }^{1,2}$, Yu Zhang ${ }^{1,2}$, Yingjuan Huang ${ }^{1,2}$, Liangliang Wang ${ }^{1,2}$ and Fei Wang ${ }^{1,2^{*}}$

\begin{abstract}
Background: $\beta$-Xylosidase is an important constituent of the hemicellulase system and it plays an important role in hydrolyzing xylooligosaccharides to xylose. Xylose, a useful monose, has been utilized in a wide range of applications such as food, light, chemical as well as energy industry. Therefore, the xylose-tolerant $\beta$-xylosidase with high specific activity for bioconversion of xylooligosaccharides has a great potential in the fields as above.

Results: A $\beta$-xylosidase gene (Tth xynB3) of 2,322 bp was cloned from the extremely thermophilic bacterium Thermotoga thermarum DSM 5069 that encodes a protein containing 774 amino acid residues, and was expressed in Escherichia coli BL21 (DE3). The phylogenetic trees of $\beta$-xylosidases were constructed using Neighbor-Joining (NJ) and Maximum-Parsimony (MP) methods. The phylogeny and amino acid analysis indicated that the Tth xynB3 $\beta$-xylosidase was a novel $\beta$-xylosidase of GH3. The optimal activity of the Tth xynB3 $\beta$-xylosidase was obtained at $\mathrm{pH}$ 6.0 and $95^{\circ} \mathrm{C}$ and was stable over a pH range of 5.0-7.5 and exhibited $2 \mathrm{~h}$ half-life at $85^{\circ} \mathrm{C}$. The kinetic parameters $K_{m}$ and $V_{\max }$ values for $p$-nitrophenyl- $\beta$-D-xylopyranoside and $p$-nitrophenyl-a-L-arabinofuranoside were $0.27 \mathrm{mM}$ and $223.3 \mathrm{U} / \mathrm{mg}, 0.21 \mathrm{mM}$ and $75 \mathrm{U} / \mathrm{mg}$, respectively. The $k_{\text {cat }} / K_{m}$ values for $p$-nitrophenyl- $\beta$-D-xylopyranoside and p-nitrophenyl-a-L-arabinofuranoside were $1,173.4 \mathrm{mM}^{-1} \mathrm{~s}^{-1}$ and $505.9 \mathrm{mM}^{-1} \mathrm{~s}^{-1}$, respectively. It displayed high tolerance to xylose, with $K_{i}$ value approximately $1000 \mathrm{mM}$. It was stimulated by xylose at higher concentration up to $500 \mathrm{mM}$, above which the enzyme activity of Tth xynB3 $\beta$-xylosidase was gradually decreased. However, it still remained approximately $50 \%$ of its original activity even if the concentration of xylose was as high as $1000 \mathrm{mM}$. It was also discovered that the Tth xynB3 $\beta$-xylosidase exhibited a high hydrolytic activity on xylooligosaccharides. When 5\% substrate was incubated with $0.3 \cup$ Tth xynB3 $\beta$-xylosidase in $200 \mu \mathrm{L}$ reaction system for $3 \mathrm{~h}$, almost all the substrate was biodegraded into xylose.
\end{abstract}

Conclusions: The article provides a useful and novel $\beta$-xylosidase displaying extraordinary and desirable properties: high xylose tolerance and catalytic activity at temperatures above $75^{\circ} \mathrm{C}$, thermally stable and excellent hydrolytic activity on xylooligosaccharides.

Keywords: Thermotoga thermarum, $\beta$-xylosidase, $a$-arabinosidase, Xylose tolerant, Hemicellulose, Thermostability, Xylooligosaccharides

\footnotetext{
* Correspondence: hgwf@njfu.edu.cn

${ }^{+}$Equal contributors

${ }^{1}$ College of Chemical Engineering, Nanjing Forestry University, Nanjing 210037, China

${ }^{2}$ Jiangsu Key Lab of Biomass-Based Green Fuels and Chemicals, Nanjing 210037, China
}

C Biomed Central
(C) 2013 Shi et al.; licensee BioMed Central Ltd. This is an Open Access article distributed under the terms of the Creative Commons Attribution License (http://creativecommons.org/licenses/by/2.0), which permits unrestricted use, distribution, and reproduction in any medium, provided the original work is properly cited. 


\section{Background}

Hemicellulose is the second most abundant renewable lignocellulosic biomass resource, in which xylan is a major component and it is mainly composed of a backbone of $\beta$-1,4-linked xylopyranosyl units with the presence of side groups' substitution such as arabinosyl, acetyl and glucuronosyl [1-3]. The thorough degradation of xylan is a multi-step action and requires the synergistic action of several hydrolytic enzymes [4]. The enzymes primarily include xylanase (EC 3.2.1.8) and $\beta$-xylosidase (EC 3.2.1.37), which can hydrolyze xylan to yield xylooligosaccharides (XOs) and xyloses, respectively [5,6]. Moreover, additional enzymes such as $\alpha$-L-arabinosidase, $\alpha$-D-glucuronidase, and acetyl xylan esterase, can cleave the side-chain of glycosyl derivatives [6]. Ultimately hydrolysates of xylan, xylose and arabinose have been found to be useful for the applications in foods and fuel industries, as well as prebiotic exploitation [2,3]. In addition, bioethanol can be produced from lignocellulosic biomass using steam or aqueous ammonia pretreatment, followed by enzymatic hydrolysis and fermentation [7,8]. Xylanases can improve the hydrolysis of cellulose into fermentable sugars by depolymerizing xylans from the cellulosehemicellulose compound, and furthermore enhance the access of cellulases to cellulose surfaces $[8,9]$. $\beta$-Xylosidases, displaying the similar function as xylanases, are important part of most microbial xylanolytic systems by attacking the non-reducing ends of XOs to release xylose or other oligosaccharides [10-13]. The catalytic process of $\beta$-xylosidases is considered as a double displacement mechanism requiring a glycosyl enzyme medium, like the catalysis of glycosidases [10]. Glycoside hydrolases, the most efficient enzymes presently known, split the glycosidic linkage between two carbohydrate residues [14]. It is well know that all the $\beta$-xylosidases are mainly divided into glycosyl hydrolase (GH) families $3,39,43,52$, and 54 based on their amino acid sequence similarities [15]. Typical substrate specificities, reaction mechanisms, and three-dimensional (3D) structures were reported in these members of each family [16]. However, a $\beta$-xylosidase from Thermoanaerobacterium saccharolyticum JW/SLYS485 does not fit into any of the $\beta$-xylosidases families [17]. These $\beta$-xylosidases families together with all the other $\mathrm{GH}$ families are readily available on the continuously updated web site (http://www.cazy.org/GlycosideHydrolases.html) [18].

Although many $\beta$-xylosidases and their coding genes have been manipulated and characterized in plant, fungi, bacteria as well as archaea, few literatures about highly thermostable $\beta$-xylosidases are available in database. Indeed, enzyme with high thermostability is essential for the industrial application in biomass degradation, as it can prolong its service life and reduce the enzyme consumption [3]. Therefore, it serves as an efficient way in bioconversion for xylan degradation at high temperature.

Thermotoga thermarum isolated from continental solfataric springs at Lac Abbe (Djibouti, Africa), is an anaerobic hyperthermophile that grows at $80^{\circ} \mathrm{C}$ and at $\mathrm{pH}$ values ranging from 5.5 to 9.0, which has been reported to produce many hydrolases including $\beta$-xylosidase [19].

In this paper, we described the cloning, expression, purification and biochemical characterizations of Tth xynB3 $\beta$-xylosidase, the novel thermostable $\beta$-xylosidase from $T$. thermarum.

\section{Results}

Cloning and sequence analysis of Tth xynB3 $\beta$-xylosidase Through the analysis of the genome sequence of T. thermarum DSM 5069, a protein (Theth_0138), defined as $\beta$-mannanase in Genbank, consists of a 2,322 bp fragment encoding 774 amino acids, which belongs to glycoside hydrolases family 3 (GH3). It shares the highest sequence similarity of $71 \%$ with the $\beta$-xylosidase from Thermotoga maritima MSB8 (Genbank No. NP_227892), and was revealed by whole-genome sequencing yet has not been biochemically characterized. Alignment of the Tth xynB3 $\beta$-xylosidase cluster with several representative members of GH3 indicated that they shared similar blocks. As we know, among all the members of GH3, aspartic acid acts as a catalytic nucleophile and glutamic acid as a catalytic proton donor. Based on present database, however, we are not able to obtain the threedimensional (3D) structure and verify the role of the two active amino acids of the Tth xynB3 $\beta$-xylosidase. By the description of $\beta$-xylosidases of $\mathrm{GH} 3$, we know that the $\beta$-xylosidases has multi-domains, such as provisional $\beta$-D-glucoside glucohydrolase (PRK15098), $\beta$-glucosidase-related glycosidases (BglX), probable $\beta$ xylosidase (PLN03080) and GH3 C-terminal domain (pfam01915) [20]. Among these $\beta$-xylosidases from different $\mathrm{GH}$ families, the average length of amino acids sequence and multi-domains of each family are apparently different (http://www.ncbi.nlm.nih.gov/).

The results indicated that the protein (Theth_0138) could be a novel $\beta$-xylosidase (detailed data were described below). The DNA fragment of a protein (Theth_0138) gene was amplified from genomic DNA of T. thermarum DSM 5069, and ligated to pET-20b at Nde $I$ and Xho $I$ sites to generate plasmid pET-20b-Tth xynB3.

\section{Expression and purification of recombinant Tth $x y n B 3$ $\beta$-xylosidase}

For functional analysis of the recombinant $\beta$-xylosidase, the plasmid pET-20b-Tth $x y n B 3$ was expressed in E. coli BL21 (DE3). The heterologous protein was over-produced by inducing cells with $0.5 \mathrm{mM}$ IPTG. The recombinant 
xylanase was purified through a heat treatment at $70^{\circ} \mathrm{C}$ for $30 \mathrm{~min}$ followed by a Ni-NTA affinity chromatography (Table 1). The extracts from the $E$. coli harboring the construct Tth xynB3 $\beta$-xylosidase displayed a single band at approximately $85 \mathrm{kD}$ by SDS-PAGE analysis (Figure 1, lane 1), and the molecular weight (MW) of Tth xynB3 $\beta$-xylosidase conformed to the theoretical MW of the monomer $(85,129 \mathrm{Da})$. Size exclusion chromatography was also performed using the $\ddot{\mathrm{A}} \mathrm{KTAFPLC} \mathrm{C}^{\mathrm{TM}}$ system to determine the oligomerization state of the target protein. It was found that the native protein formed 5-mer in solution with a calculated MW 422, 474 Da according to the calibration curve of the gel filtration column.

\section{Biochemical properties of Tth xynB3 $\beta$-xylosidase}

The Tth xynB3 $\beta$-xylosidase exhibited the highest enzyme activity at $\mathrm{pH}$ 6.0, while its relative activity all remained high, approximately $70 \%$ of the maximum activity, with the $\mathrm{pH}$ ranging from 5.0 to 7.0 (Figure $2 \mathrm{a}$ ). The $\beta$-xylosidase exhibited its optimal activity at $95^{\circ} \mathrm{C}$ (Figure $2 \mathrm{~b}$ ), and it retained more than $50 \%$ of its initial activity at $75^{\circ} \mathrm{C}-85^{\circ} \mathrm{C}$ for $2 \mathrm{~h}$ when tested at $\mathrm{pH} 6.0$ (Figure 2c), and as indicated the half-life of the recombinant $\beta$-xylosidase was approximately $2 \mathrm{~h}$ at $85^{\circ} \mathrm{C}$.

The effects of cations and chemical reagents on the enzyme activity were also investigated, and the results were shown in Table 2 . In various assays, the enzyme activity was significantly influenced by $1 \mathrm{mM}$ concentration of $\mathrm{Cu}^{2+}, \mathrm{Zn}^{2+}, \mathrm{Al}^{3+}, \mathrm{Mn}^{2+}$ and $\mathrm{Co}^{2+}$ and $10 \mathrm{mM}$ concentration of $\mathrm{Ni}^{2+}, \mathrm{Zn}^{2+}, \mathrm{Mn}^{2+}, \mathrm{Ba}^{2+}$ and EDTA. In addition, $0.05 \%$ Tween 60 and Tris also significantly affected the enzyme activity. The results of biochemical properties for $\alpha$-arabinosidase were almost the same as those of the $\beta$-xylosidase (data was not detailed in this paper).

\section{Effect of xylose on Tth xynB3 $\beta$-xylosidase activity and substrate specificity}

The enzyme was able to hydrolyze $p$-nitrophenyl- $\beta$ $\mathrm{D}$-xylopyranoside ( $p \mathrm{NPX})$ and $p$-nitrophenyl- $\alpha$-Larabinofuranoside ( $p$ NPAF), and almost no other glycosidase activity was detected over $p$-nitrophenyl$\beta$-D-glucopyranoside, $p$-nitrophenyl $\alpha$-D-glucopyranoside, caboxy methyl cellulose (CMC), linear arabinan and sucrose. The dependence of the enzymatic reaction rate on the substrates concentration followed MichaelisMenten kinetics, with the kinetic parameters $K_{m}$ and $V_{\max }$ values of $0.27 \mathrm{mM}$ and $223.3 \mathrm{U} / \mathrm{mg}$ for $p \mathrm{NPX}$, $0.21 \mathrm{mM}$ and $75.0 \mathrm{U} / \mathrm{mg}$ for pNPAF under optimal conditions. The $k_{\text {cat }} / K_{m}$ value for $p$-nitrophenyl- $\alpha$-Larabinofuranoside was $505.9 \mathrm{mM}^{-1} \mathrm{~s}^{-1}$. The $k_{\text {cat }} / K_{m}$ value of $1173.4 \mathrm{mM}^{-1} \mathrm{~s}^{-1}$ for $p \mathrm{NPX}$ was significantly higher than that of $\beta$-xylosidase from Aspergillus awamori [15]. However, the turnover number $k_{\text {cat }}$ for $p$ NPX was 3.1fold than that of $p$ NPAF, and the catalytic efficiency constant $k_{c a t} / K_{m}$ was 2.3 -fold than that of $p$ NPAF. The activity of Tth xynB3 $\beta$-xylosidase was stimulated by xylose at concentrations up to $500 \mathrm{mM}$. In the presence of $200 \mathrm{mM}$ xylose, enzyme activity increased to a maximum value with $20 \%$ more than that of the control without xylose (Figure 3). With further increase of the xylose, the enzyme activity of Tth xynB3 $\beta$-xylosidase was gradually inhibited, with a $K_{i}$ of $1000 \mathrm{mM}$ xylose (Figure 3 ). The enzymatic characteristics of the xylose-tolerant $\beta$-xylosidase from other microorganisms were summarized in Table 3. This implies that these enzymes possess many distinct features, especially in their catalytic properties.

\section{Xylooligosaccharides degradation of Tth xynB3 $\beta$-xylosidase}

Production of xyloses by the purified Tth xynB3 $\beta$-xylosidase was examined using the thin layer chromatography (TLC) (Figure 4). The xyloses were generated from $10 \%$ XOs (isopyknic xylobiose, xylotriose and xylotetraose respectively) or from the hydrolysis of cornstalk by xylanse. After the hydrolysis for $3 \mathrm{~h}$, the XOs from both sources were found to be biodegraded into xylose completely, and the final concentration of xylose in the reaction reached at approximately $360 \mathrm{mM}$.

\section{Phylogenies analysis of Tth xynB3 $\beta$-xylosidase}

To gain deeper insight into the evolutionary relationship among $\beta$-xylosidases, the phylogenetic trees generated from 55 candidate sequences were constructed using the NJ method and the MP method separately; both

Table 1 Purification of the recombinant Tth xynB3 $\beta$-xylosidase

\begin{tabular}{|c|c|c|c|c|c|c|}
\hline Purification step & Total volume $(\mathrm{mL})$ & Total activity (U) & Total protein $(\mathrm{mg})$ & Specific activity (U/mg) & Recovery (\%) & Purification (fold) \\
\hline$\overline{\text { Crude extract }^{a}}$ & 10 & 2394 & 122 & 20 & 100 & 1 \\
\hline Heat treatment ${ }^{b}$ & 10 & 2155 & 39 & 55 & 90 & 2.8 \\
\hline $\mathrm{Ni}$ affinity chromatography ${ }^{c}$ & 1 & 2011 & 17 & 116 & 84 & 5.8 \\
\hline
\end{tabular}

${ }^{a}$ The recombinant strain was grown in LB medium $(200 \mathrm{ml})$ with $1 \mu \mathrm{g}$ ampicillin/ml at $37^{\circ} \mathrm{C}$ to $\mathrm{OD}_{600} 0.8$ and was incubated further with isopropyl- $\beta$-thiogalactopyranoside (IPTG) for $12 \mathrm{~h}$. The cells were harvested by centrifugation at $10,000 \mathrm{~g}$ for $15 \mathrm{~min}$ at $4^{\circ} \mathrm{C}$ and resuspended in $10 \mathrm{ml}$ imidazole buffer (10 $\mathrm{mL}$ of $5 \mathrm{mM}$ imidazole, $0.5 \mathrm{mM}$ $\mathrm{NaCl}$, and $20 \mathrm{mM}$ Tris- $\mathrm{HCl}$ buffer, $\mathrm{pH} 7.9$ ), followed by sonication.

${ }^{b}$ The cell extracts after sonication were heat treated at $70^{\circ} \mathrm{C}$ for $30 \mathrm{~min}$, and then cooled in an ice bath, centrifuged at $15,000 \mathrm{~g}$ for $20 \mathrm{~min}$ at $4^{\circ} \mathrm{C}$ and the supernatant was kept.

c The obtained supernatants were loaded on to an immobilized metal affinity column (Novagen, USA), and eluted with $0.4 \mathrm{M}$ imidazole, $0.5 \mathrm{M} \mathrm{NaCl}$, and $20 \mathrm{mM}$ Tris- $\mathrm{HCl}$ buffer (pH 7.9). 


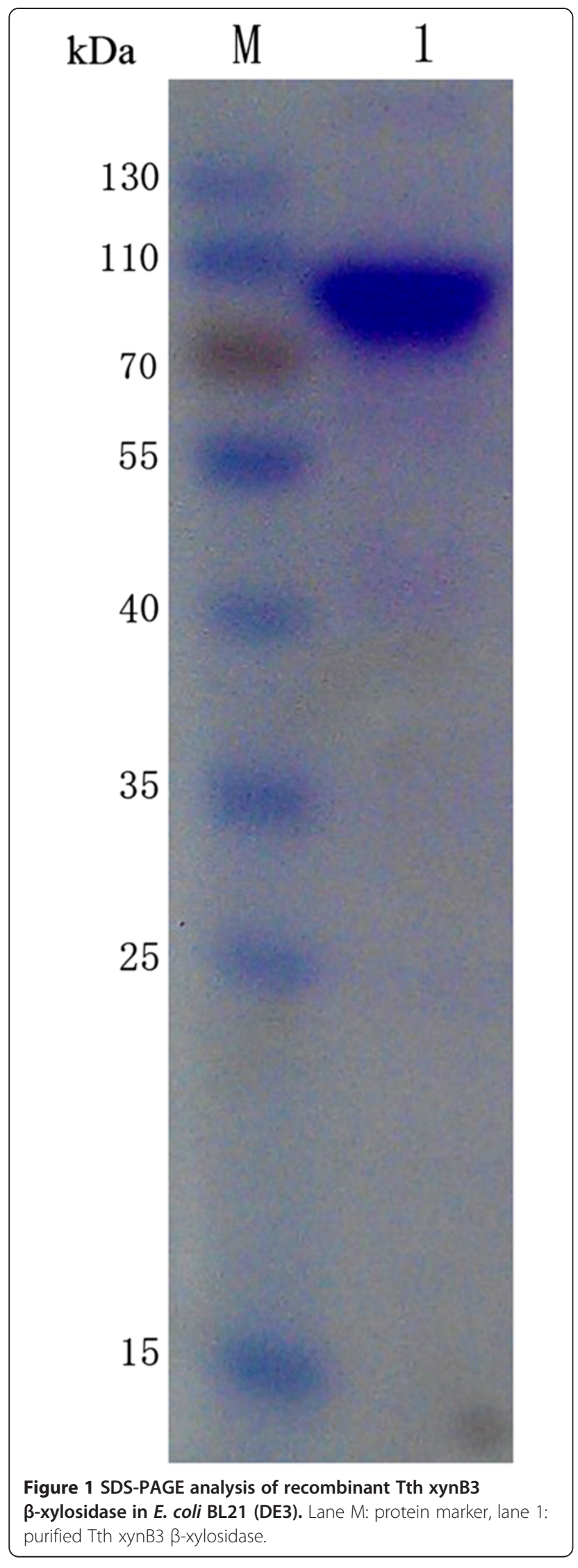

supported almost the same topological structures (NJ tree was not shown). The phylogenetic trees revealed the presence of five well-supported clades and each clade consisted of a separated monophyletic group. Clade I was the GH39 $\beta$-xylosidases from bacteria, Clade II was the GH3 $\beta$-xylosidases from bacteria, archaea and fungi, Clade III was the GH52 $\beta$-xylosidases from bacteria, Clade IV was the GH54 $\beta$-xylosidases from bacteria and Clade V was the GH43 $\beta$-xylosidases from bacteria and archaea. Among these families, the members of $\beta$-xylosidases in GH39, GH52 and GH54 were all from bacteria, and almost no information was available in fungi and archaea. However, other $\beta$-xylosidases in GH3 and GH43 were widely distributed. Clade II mainly contained mesophilic strains, thermophiles and hyperthermophiles. From the phylogenetic tree it was exhibited that there were several subclades in Clade II, among which the members of hyperthermophilic genus Thermotoga had a close relationship with Petrotoga mobilis and other hyperthermophiles, and $T$. thermarum Tth xynB3 $\beta$-xylosidase clustered together with the same genus Thermotoga $\beta$-xylosidases (Figure 5). Located at the boundary of the genus Thermotoga, $\beta$-xylosidases from T. thermarum and T. lettingae shared apparently distant relationship with the $T$. petrophila $\beta$-xylosidase. Therefore, it was postulated that their biochemical properties might be different.

\section{Discussions}

Based on amino acid sequence similarities, 130 families were found in Glycoside Hydrolases, among which GH 3, $39,43,52$, and 54 contained $\beta$-xylosidases [15]. Through the blast at GenBank, the amino acid sequence analysis indicated that Tth xynB3 $\beta$-xylosidase belonged to GH3, and it shared the highest sequence similarity of $71 \%$ with the $\beta$-xylosidase from Thermotoga sp. (ZP_10919422) and the Thermotoga maritima (NP_227892). Moreover, it also shared the $71 \%$ similarity with the putative $\beta$-mannanase from the Thermotoga neapolitana (YP_002534158). So far as we know, the amino acid sequences of Tth xynB3 $\beta$-xylosidase was described as a $\beta$-mannanase in NCBI database. However, it has been confirmed as a $\beta$-xylosidase in details as described above. In most cases, two glutamic acid residues, or aspartic acid and glutamic acid residues are the catalytic nucleophile and proton donor in glycosyl hydrolases. However, the optimal template on database for homology modeling is $2 \mathrm{X} 41 \mathrm{~A}$, which only shared $30 \%$ similarity with the Tth xynB3 $\beta$-xylosidase. Thus, no 3D structure of the Tth xynB3 $\beta$-xylosidase was obtained. Furthermore, it's hard to distinguish which two amino acids are the catalytic nucleophile and proton donor in Tth xynB3 $\beta$-xylosidase.

This is the first report on the purification and characterization of a Tth xynB3 $\beta$-xylosidase from 

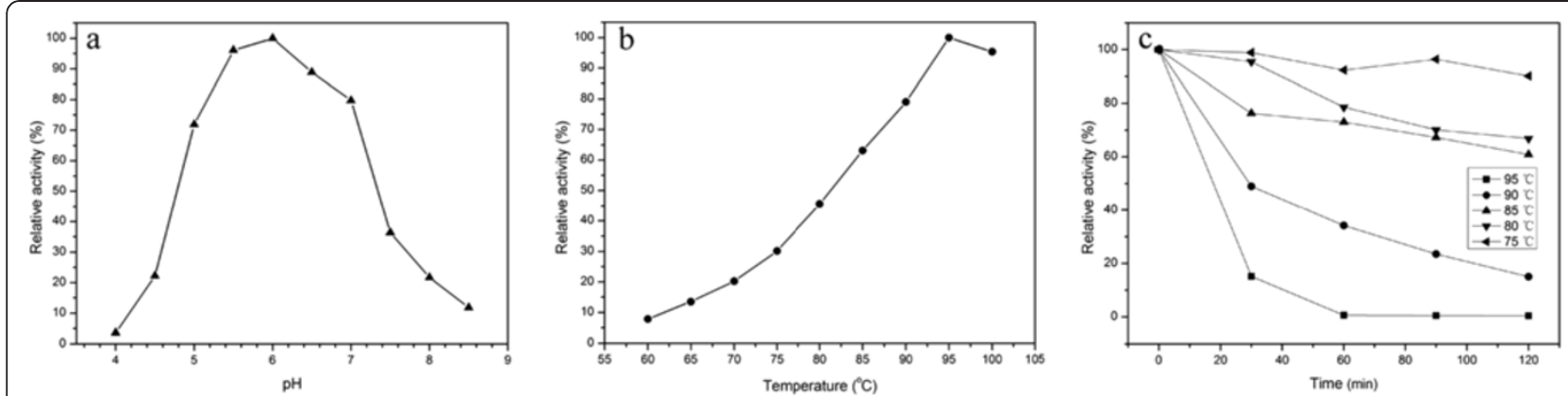

Figure 2 Effects of $\mathrm{pH}$ and temperature on the activity and stability of the recombinant Tth $\mathrm{xynB} 3 \boldsymbol{\beta}$-xylosidase. a) Effect of pH on Tth xynB3 $\beta$-xylosidase activity. b) Effect of temperature on Tth xynB3 $\beta$-xylosidase activity. c) The thermostability of the Tth xynB3 $\beta$-xylosidase. The residual activity was monitored while the enzyme was incubated at $75^{\circ} \mathrm{C}$ (filled left triangles), $80^{\circ} \mathrm{C}$ (filled down triangles), $85^{\circ} \mathrm{C}$ (filled up triangles), $90^{\circ} \mathrm{C}$ (filled circles) and $95^{\circ} \mathrm{C}$ (filled squares). The maximum activity was defined as $100 \%(\mathbf{a}, \mathbf{b}$ ) or initial activity was defined as $100 \%$ (c).

T. thermarum. The Phylogenies analysis and enzymatic properties showed that the Tth xynB3 $\beta$-xylosidase was distant with the xylose-tolerant $\beta$-xylosidase from Paecilomyces thermophila and Scytalidium thermophilum $[21,22]$ (Table 3$)$. The phylogenetic tree also revealed a close relationship between $T$. thermarum $\beta$-xylosidase and T. maritima $\beta$-xylosidase. T.maritima $\beta$-xylosidase has been described as a hyperthermophilic $\beta$-xylosidase with high thermostability at temperature $80^{\circ} \mathrm{C}$ [23]. Other $\beta$-xylosidases of genus Thermotoga including $T$. thermarum $\beta$-xylosidase have not been studied yet. As $71 \%$ amino acid sequences similarity was found

Table 2 Effects of cations and chemical reagents on purified Tth xynB3 $\beta$-xylosidase activity

\begin{tabular}{|c|c|}
\hline Cations $^{\mathrm{a}}$ & Residual activity (\%) \\
\hline Control & 100 \\
\hline $\mathrm{Mg}^{2+}$ & $102 / 99$ \\
\hline $\mathrm{Zn}^{2+}$ & $85 / 33$ \\
\hline $\mathrm{Mn}^{2+}$ & $107 / 117$ \\
\hline $\mathrm{Ba}^{2+}$ & $99 / 187$ \\
\hline $\mathrm{Ca}^{2+}$ & 99/96 \\
\hline $\mathrm{Al}^{3+}$ & $87 / \mathrm{ND}^{c}$ \\
\hline $\mathrm{Cu}^{2+}$ & $4 / 2$ \\
\hline $\mathrm{CO}^{2+}$ & $89 / N D$ \\
\hline $\mathrm{Ni}^{2+}$ & $100 / 63$ \\
\hline \multicolumn{2}{|c|}{ Chemical reagents ${ }^{\mathrm{b}}$} \\
\hline EDTA & $103 / 114$ \\
\hline Tween 60 & 105/ND \\
\hline Tris & 107/ND \\
\hline$\underline{S D S}$ & $98 / N D$ \\
\hline \multicolumn{2}{|c|}{$\begin{array}{l}\text { ainal concentration, the former value in the table was determined at } 1 \mathrm{mM} \\
\text { and the latter was determined at } 10 \mathrm{mM} \text {. }{ }^{\mathrm{b}} \text { Final concentration, the values in } \\
\text { the table were determined at } 1 \mathrm{mM} \text { (or } 10 \mathrm{mM} \text {, the latter values), } 0.05 \% \text {, } \\
0.05 \% \text { and } 0.1 \% \text { for EDTA, Tween } 60 \text {, Tris, and SDS, respectively. }{ }^{\mathrm{C}} \mathrm{ND} \text { : not } \\
\text { determined. Values shown were the means of duplicate experiments, and the } \\
\text { variations about the means were below } 5 \% \text {. }\end{array}$} \\
\hline
\end{tabular}

between $T$. thermarum $\beta$-xylosidase and T. maritime $\beta$-xylosidase, it was inferred that the Tth xynB3 $\beta$ xylosidase could be a novel hyperthermophilic $\beta$-xylosidase with some specific properties.

Lignocellulosic biomass includes approximately $70 \%$ cellulose and 30\% xylan [24]. Enhancing the biodegradation performance of hemicellulases on lignocellulosic biomass is of considerable significance for biorefinery [25]. Hemicellulose, which is mainly composed of xylan, a ubiquitous component of plants, consists of polysaccharides, each reflecting polydispersity, polymolecularity, and polydiversity. $\beta$-xylosidase is known to be the key enzyme for converting XOs to xylose which is the main endproduct of xylan [22]. To our knowledge, xylose is a strong inhibitor of $\beta$-xylosidases. Therefore, $\beta$-xylosidases with high tolerance for xylose have great potential in conversion of hemicellulose in many fields. With the knowledge that most $\beta$-xylosidases are sensitive to the xylose,

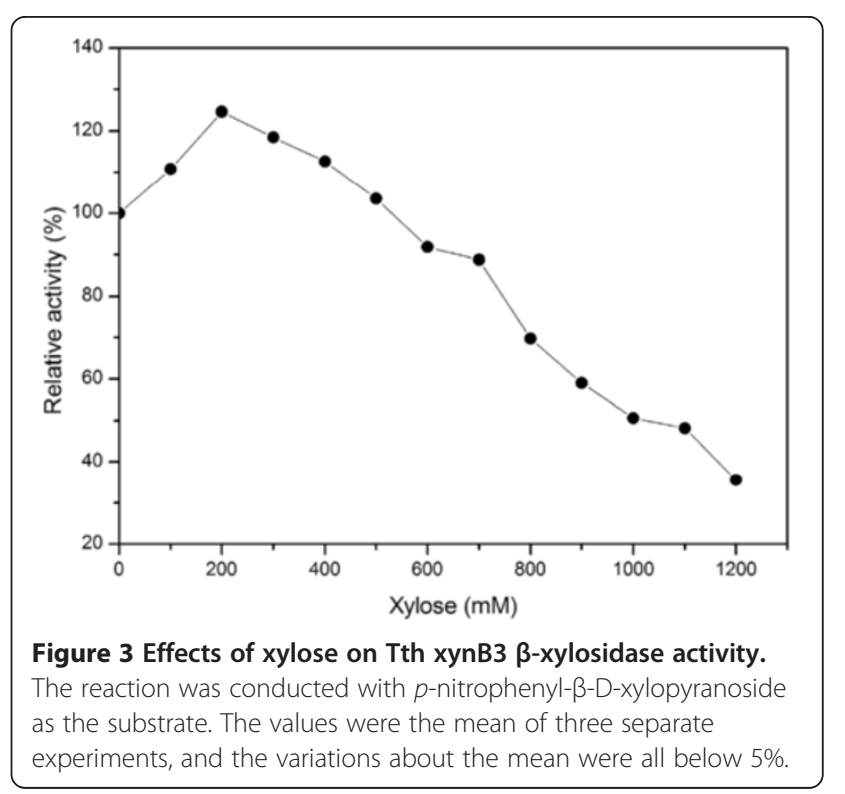


Table 3 Characteristics of highly xylose-tolerant $\beta$-xylosidase from $T$. thermarum DSM 5069 and other microorganisms

\begin{tabular}{|c|c|c|c|c|c|c|c|c|}
\hline \multirow[t]{2}{*}{ Strain } & \multicolumn{2}{|c|}{$K_{m}(\mathrm{mM})$} & \multicolumn{2}{|c|}{$V_{\max }(\mathrm{U} / \mathrm{mg})$} & \multirow{2}{*}{$\begin{array}{l}K_{i} \text { for xylose } \\
(\mathrm{mM})\end{array}$} & \multicolumn{2}{|c|}{$k_{c a t} / K_{m}\left(\mathrm{mM}^{-1} \mathrm{~s}^{-1}\right)$} & \multirow{2}{*}{$\begin{array}{l}\text { Optimal temp } \\
\left({ }^{\circ} \mathrm{C}\right)\end{array}$} \\
\hline & ${ }^{a} p N P X$ & ${ }^{\mathrm{b} p N P A F}$ & pNPX & $\overline{p N P A F}$ & & $\overline{p N P X}$ & pNPAF & \\
\hline T. thermarum & 0.27 & 0.21 & 223.2 & 75.0 & 1000 & 1173.4 & 505.9 & 95 \\
\hline d Unnamed bacterium [26] & 3.43 & 2.23 & ${ }^{\mathrm{c}} \mathrm{ND}$ & ND & 76.0 & 8.1 & 2.5 & 40 \\
\hline Paecilomyces thermophila [22] & 4.3 & ND & ND & ND & 139 & ND & ND & 55 \\
\hline Scytalidium thermophilum [21] & 1.3 & ND & 88 & ND & ${ }^{e}<600$ & ND & ND & 60 \\
\hline
\end{tabular}

a $p$ NPX: $p$-nitrophenyl- $\beta$-D-glucopyranoside.

b $p$ NPAF: $p$-nitrophenyl-a-L-arabinofuranoside.

c ND: not determined.

${ }^{d}$ Isolated from yak rumen.

e Calculated by the data based on the reference [21].

especially the $\beta$-xylosidases from fungi, such as Arxula adeninivorans, Aureobasidium pullulans and Trichoderma Reesei exhibiting a $K i$ for xylose ranging from 2 to $10 \mathrm{mM}$ [21]. However, the $\beta$-xylosidases from Paecilomyces thermophila and Scytalidium thermophilum exhibited a certain tolerance to xylose (Table 3). It was surprising to find that when concentration of xylose was up to $500 \mathrm{mM}$, it did not decrease the $T$. thermarum $\beta$-xylosidase activity, implying a very high tolerance to the inhibition by its hydrolysis product xylose. Thus, the effect of xylose on the Tth xynB3 $\beta$-xylosidase activity revealed that the enzyme was not only resistant to the endproduct inhibition, but was also activated by xylose at concentrations less than $500 \mathrm{mM}$. Compared with other $\beta$-xylosidases, the $K_{i}$ for xylose of Tth xynB3 $\beta$-xylosidase was higher than that from Paecilomyces thermophila, an unnamed bacterium isolated from yak rumen, and other reported $\beta$-xylosidases (Table 3).
Moreover, high specific activity for XOs is also demanded for $\beta$-xylosidase in enzymatic hydrolysis of hemicellulose. The $V_{\max }$ value of Tth xynB3 $\beta$-xylosidase for $p$ NPX was $223.3 \mathrm{U} / \mathrm{mg}$, which was approximately 3 -fold higher than that of for $p$ NPAF. It has been reported that the specific activity of a xylose highly tolerant $\beta$-xylosidase from $S$. thermophilum for $p$ NPX is $65 \mathrm{U} / \mathrm{mg}$, which is nearly 2 -fold less than the Tth xynB3 $\beta$-xylosidase [21]. The Tth xynB3 $\beta$-xylosidase was discovered to be the only $\beta$-xylosidase displayed insensitive to xylose yet had higher specific activity for $p \mathrm{NPX}$ and $p$ NPAF. The $k_{\text {cat }} / K_{m}$ of Tth xynB3 $\beta$-xylosidase for $p$ NPX was $1173.4 \mathrm{mM}^{-1} \mathrm{~s}^{-1}$, approximately 400-fold higher than the $\beta$-xylosidase from Bacillus halodurans and 100 -fold higher than the $\beta$-xylosidase from the unnamed bacterium [26,27]. Therefore, the Tth xynB3 $\beta$-xylosidase exhibited unexceptionable potential for bioconversion.

The cations $(1 \mathrm{mM}$ or $10 \mathrm{mM})$ investigated in this study had various effects on the activity of Tth xynB3
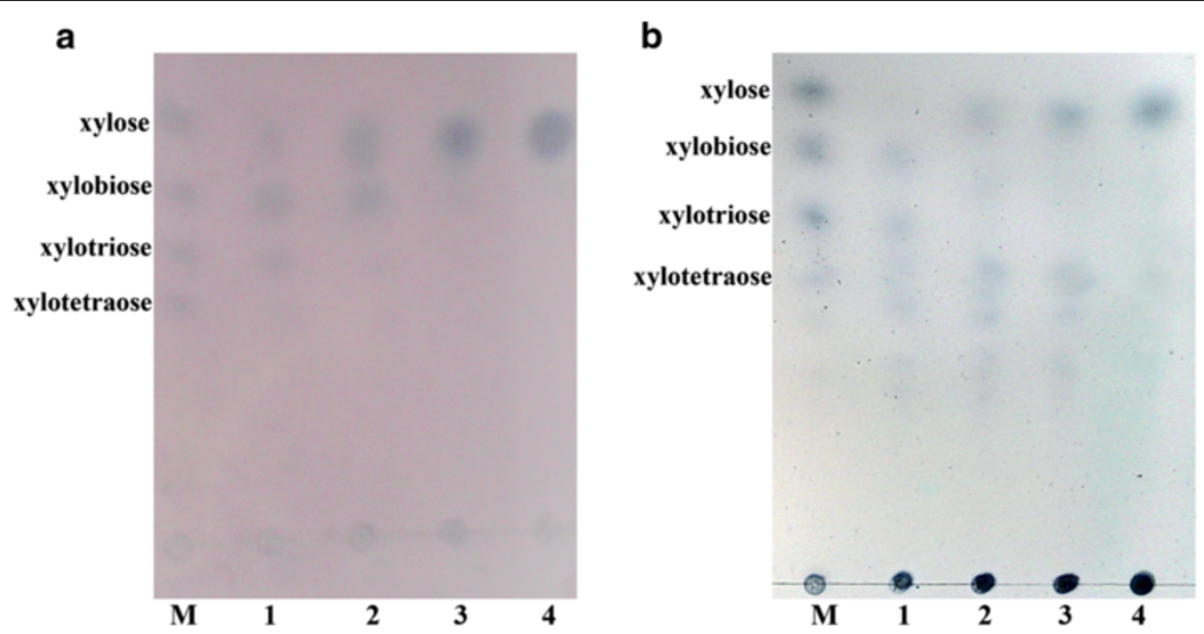

Figure 4 Analysis of xylooligosaccharides hydrolyzed by Tth xynB3 $\beta$-xylosidase. The products of the reaction were determined using thin layer chromatography. $\mathrm{M}$, mixture of xylose, xylobiose, xylotriose and xylotetraose (2.5\% each, wt/vol). a Lane 1, 2, 3, 4: samples of xylobiose, xylotriose and xylotetraose (5\%, wt/vol) incubated with Tth xynB3 $\beta$-xylosidase $(0.3 \mathrm{U})$ for $0.5 \mathrm{~h}, 1 \mathrm{~h}, 2 \mathrm{~h}$, 3h, respectively. $\mathbf{b}$ Lane 1: samples of XOs obtained from cornstalk without hydrolysis using Tth xynB3 $\beta$-xylosidase, lane 2, 3, 4: samples of XOs obtained from cornstalk incubated with Tth xynB3 $\beta$-xylosidase $(0.3 \mathrm{U})$ for $1 \mathrm{~h}, 2 \mathrm{~h}, 3 \mathrm{~h}$, respectively. 


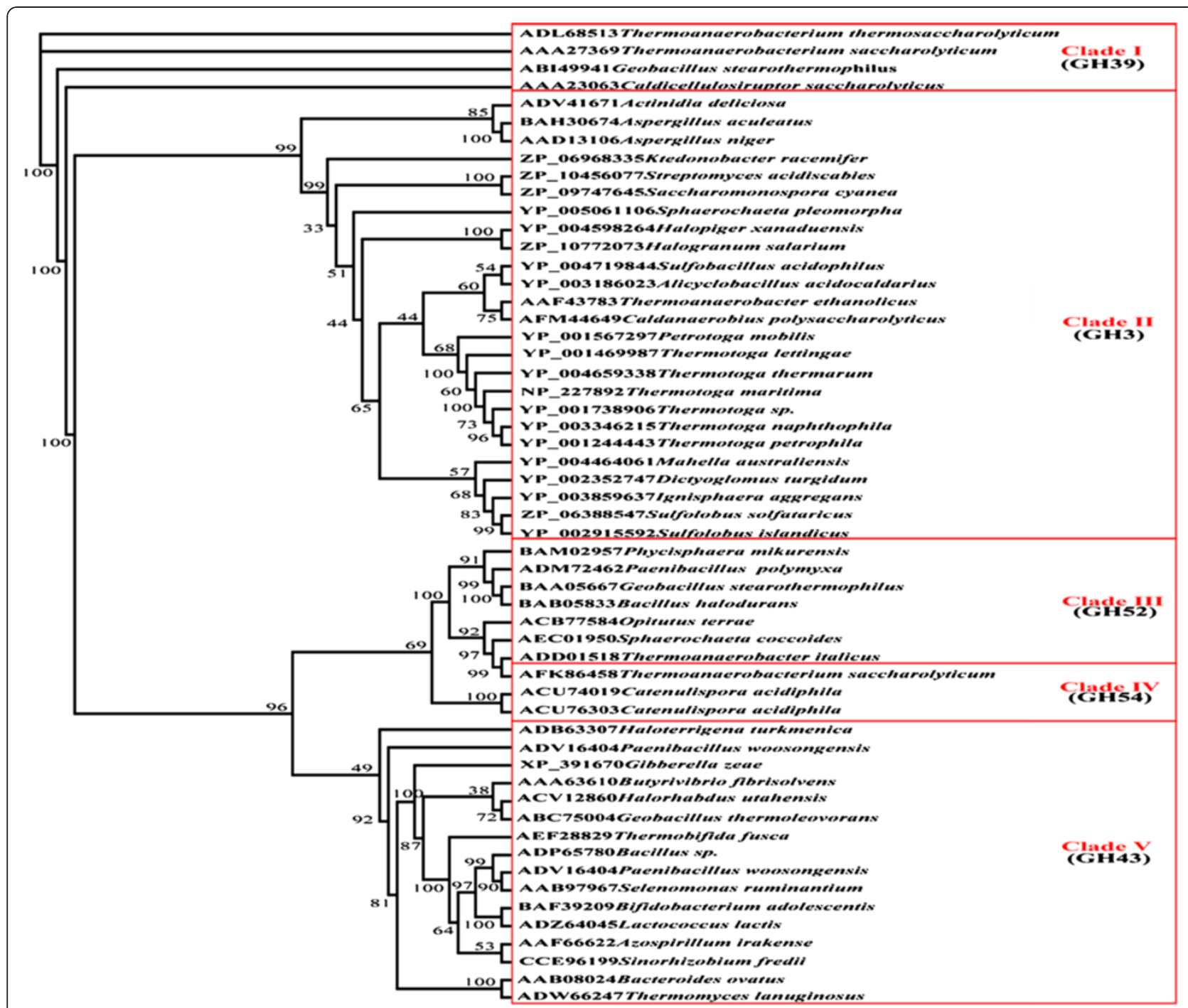

Figure 5 Maximum-Parsimony (MP) tree results from analysis of Tth xynB3 $\beta$-xylosidases of 55 amino acid sequences. Numbers on nodes correspond to percentage bootstrap values for 1000 replicates.

$\beta$-xylosidase. As described in Table 2, $1 \mathrm{mM}$ (or $10 \mathrm{mM}$ ) concentration of $\mathrm{Co}^{2+}, \mathrm{Zn}^{2+}, \mathrm{Cu}^{2+}, \mathrm{Al}^{3+}$ and $\mathrm{Ni}^{2+}$ inhibited the enzyme activity significantly, while $\mathrm{Ba}^{2+}$ and $\mathrm{Mn}^{2+}$ enhanced the enzyme activity. It was interesting to find that the Tth xynB3 $\beta$-xylosidase was slightly influenced by $\mathrm{Ca}^{2+}$, which distinguished Tth xynB3 $\beta$-xylosidase from the other $\beta$-xylosidases that $\mathrm{Ca}^{2+}$ strongly stimulated the activity $[21,28,29]$. It was also found that the Tth xynB3 $\beta$-xylosidase could also be activated by chemical reagents significantly such as $0.05 \%$ tween $60,0.05 \%$ tris and $10 \mathrm{mM}$ EDTA. The capability of resisting these chemical reagents and cations indicated that the $\mathrm{Tth}$ xynB3 $\beta$-xylosidase could survive in specific conditions as described above. It is known that the longer active life means the less consumption of the enzyme [30]. Therefore, the enzymes with high thermostability are especially demanded in industrial applications such as in the field of bioconvertion. The residual activity of Tth xynB3 $\beta$-xylosidase residual activity was more than $50 \%$ of its initial activity after being incubated at $75^{\circ} \mathrm{C}-85^{\circ} \mathrm{C}$ for $2 \mathrm{~h}$, and the enzymatic hydrolysis of XOs exhibited a high activity in a broad temperature range from $75^{\circ} \mathrm{C}$ to $100^{\circ} \mathrm{C}$.

The capability of the $\beta$-xylosidase to hydrolyze XOs was investigated by using $5 \%$ substrate incubated with the purified enzyme at $75^{\circ} \mathrm{C}$. In $100 \mu \mathrm{L}$ reaction system, the XOs were completely biodegraded to xylose by $0.3 \mathrm{U}$ purified Tth xynB3 $\beta$-xylosidase after $3 \mathrm{~h}$ (Figure 4), and the total monose xylose concentration reached at $360 \mathrm{mM}$. However, under this condition, the xylose did not affect enzymatic reaction. Same as the other $\beta$-xylosidases, Tth xynB3 $\beta$-xylosidase was also active on xylobiose, xylotriose and xylotetraose [31,32]. The 
results illustrated that the Tth xynB3 $\beta$-xylosidase exhibited high ability for converting the XOs into xylose monomers.

\section{Conclusions}

In this study, a novel $\beta$-xylosidase, Tth xynB3 $\beta$-xylosidase, from T. thermarum DSM 5069 was obtained with a few specific features, as well as the high activity of $\alpha$-arabinosidase. The Phylogenetic analysis showed that Tth xynB3 $\beta$-xylosidase had close relationship with the $\beta$-xylosidase from hyperthermophile, and was distant with other xylose-tolerant $\beta$-xylosidases. Compared with the enzyme properties from other microorganisms, the Tth xynB3 $\beta$-xylosidase possessed higher tolerance to xylose, higher efficiency in XOs hydrolysis and higher thermostability. Therefore, this study provides a novel and useful $\beta$-xylosidase $/ \alpha$-arabinosidase with combined properties of high thermostability and xylose-tolerance. These characteristics constitute a powerful tool for improving the enzymatic conversion of hemicellulose to xylose through synergetic action.

\section{Materials and methods}

\section{Bacterial strains, plasmids and growth media}

Thermotoga thermarum DSM 5069 was purchased from DSMZ (www.dsmz.de). It was grown anaerobically at $80^{\circ} \mathrm{C}$ as described [19]. Escherichia coli Top10 and BL21 (DE3) cells were grown at $37^{\circ} \mathrm{C}$ in Luria-Bertani (LB) medium and supplemented with ampicillin when required. The expression vectors pET-20b (Novagen) were used as cloning and expression vector.

\section{DNA manipulation}

DNA was operated by standard procedures. Plasmid Kit and Gel Extraction Kit (BIOMIGA, Shanghai) were used to purify the plasmids and PCR products. DNA restriction endonucleases and T4 DNA ligase were purchased from TaKaRa (Dalian, China). DNA transformation was carried out by electroporation using Gene Pulser (Bio-Rad, USA).

\section{Plasmid constructions}

The DNA fragment with a size of about 2,300 bp was amplified from $T$. thermarum DSM 5069 genomic DNA with the primers Tth xynB3-1 and Tth xynB3-2 (Table 4). Fragments from the amplified DNA were then digested with Nde $I$ and Xho $I$ endonuclease and inserted into $\mathrm{pET}-20 \mathrm{~b}$ vector at the corresponding sites, yielding the plasmid pET-20b-Tth xynB3.

\section{Expression and purification}

Plasmid pET-20b-Tth xynB3 was transformed into E. coli BL21 (DE3), and induced to express recombinant Tth $x y n B 3 \quad \beta$-xylosidase by adding isopropyl- $\beta-D-$ thiogalactopyranoside (IPTG) to final concentration of
Table 4 Nucleotide sequences of the primers used

\begin{tabular}{ll}
\hline Primer & Nucleotide sequence \\
\hline Tth xynB3-1 & 5'-GGAATTCCATATGGATCTTTACAAGAATCCAAATGTAC-3' \\
Tth xynB3-2 & 5'-CCGCTCGAGCTCGATCTTTGTATTTGTGAAGAAAAC-3' \\
\hline
\end{tabular}

$0.5 \mathrm{mM}$ at $\mathrm{OD}_{600}$ approximately 0.8 , and incubated further at $30^{\circ} \mathrm{C}$ for about $12 \mathrm{~h}$.

$200 \mathrm{~mL}$ of the recombinant cells carrying pET-20b-Tth $x y n B 3$ were harvested by centrifugation $(10,000 \mathrm{~g}, 15 \mathrm{~min}$, $4^{\circ} \mathrm{C}$ ), and washed twice with distilled water, resuspended in $5 \mathrm{~mL}$ of $5 \mathrm{mM}$ imidazole, $0.5 \mathrm{mM} \mathrm{NaCl}$, and $20 \mathrm{mM}$ Tris$\mathrm{HCl}$ buffer ( $\mathrm{pH}$ 7.9). The cell extracts after sonication were heat treated $\left(70^{\circ} \mathrm{C}, 30 \mathrm{~min}\right)$, and then cooled in an ice bath, and centrifuged $\left(15,000 \mathrm{~g}, 4^{\circ} \mathrm{C}, 20 \mathrm{~min}\right)$. The obtained supernatants were loaded on to an immobilized metal affinity column $(2 \mathrm{~mL})$ (Novagen, USA) with a flow rate $0.2 \mathrm{~mL} \mathrm{~min}^{-1}$. Finally, $1 \mathrm{~mL}$ fractions were collected by eluting with $0.4 \mathrm{M}$ imidazole, $0.5 \mathrm{M} \mathrm{NaCl}$, and $20 \mathrm{mM}$ Tris-HCl buffer ( $\mathrm{pH}$ 7.9). SDS-PAGE was carried out to verify the purity of the target proteins [33], and the protein bands were analyzed using an image analysis system (Bio-Rad, USA). Purified protein concentration was determined by the Bradford method using albumin from bovine serum (BSA) as a standard. Oligomerization state of Tth xynB3 $\beta$-xylosidase was determined by size exclusion chromatography on a $\ddot{A}$ KTAFPLC ${ }^{\mathrm{TM}}$ (GE Healthcare Life Sciences) system with a Superdex 200 10/30 GL column as described by Zhang et al. [34].

\section{$\beta$-Xylosidase/ $\mathbf{a}$-arabinosidase assays}

Substrate $p$-nitrophenyl- $\beta$-D-xylopyranoside ( $p$ NPX, Sigma, USA) was used for $\beta$-xylosidase activity analysis and $p$-nitrophenyl- $\alpha$-L-arabionfuranoside ( $p$ NPAF, Sigma, USA) for $\alpha$ - arabinosidase activity analysis. Under standard assay condition, the purified enzyme $(0.1 \mu \mathrm{g})$ was incubated with $10 \mu \mathrm{L}$ of $20 \mathrm{mM}$ substrate pNPX or pNPAF in $50 \mathrm{mM}$ imidole-potassium buffer ( $\mathrm{pH}$ 6.0) for $20 \mathrm{~min}$ at $85^{\circ} \mathrm{C}$. The total reaction volume was $0.2 \mathrm{~mL}$. Subsequently, $600 \mu \mathrm{l}$ of $1 \mathrm{M} \mathrm{Na}_{2} \mathrm{CO}_{3}$ was added to stop the reaction. The $p$-nitrophenol absorbance $(p \mathrm{NP})$ was measured at $405 \mathrm{~nm}$. One unit of $\beta$-xylosidase or $\alpha$-L-arabinosidase activity was defined as the amount of enzyme releasing $1 \mu \mathrm{mol} p \mathrm{NP}$ per minute. All enzymatic activities shown in figures are average values of three separate determinations.

The optimum $\mathrm{pH}$ for $\beta$-xylosidase was determined by incubation at various $\mathrm{pH}(\mathrm{pH} 4.0-8.5)$ at $85^{\circ} \mathrm{C}$ for $20 \mathrm{~min}$ in $50 \mathrm{mM}$ imidole-potassium buffer. The optimum temperature for the enzyme activity was determined by standard assay ranging from $60^{\circ} \mathrm{C}$ to $100^{\circ} \mathrm{C}$ in $50 \mathrm{mM}$ imidole-potassium buffer at $\mathrm{pH}$ 6.0. The results were expressed as relative activity to the value obtained at either optimum temperature or optimum $\mathrm{pH}$. Thermostability assays were determined by measuring residual $\beta$-xylosidase 
or $\alpha$-arabinosidase activity after pre-incubation of enzymes at $75^{\circ} \mathrm{C}, 80^{\circ} \mathrm{C}, 85^{\circ} \mathrm{C}, 90^{\circ} \mathrm{C}$ and $95^{\circ} \mathrm{C}$ for $30 \mathrm{~min}, 60 \mathrm{~min}, 90$ $\mathrm{min}$ and $120 \mathrm{~min}$. The activity of the enzyme without preincubation was defined as $100 \%$.

The effects of metal ions and chemical reagents on $\beta$-xylosidase or $\alpha$-L-arabinosidase activity of purified enzyme $(0.1 \mu \mathrm{g})$ were determined. $\mathrm{Mg}^{2+}, \mathrm{Zn}^{2+}, \mathrm{Mn}^{2+}, \mathrm{Ca}^{2+}$, $\mathrm{Al}^{3+}, \mathrm{Ni}^{2+}, \mathrm{Cu}^{2+}$ and $\mathrm{Co}^{2+}$ were assayed at concentrations of $1 \mathrm{mM}$ (or $10 \mathrm{mM}$ ) in the reaction mixture. The chemical reagents EDTA ( $1 \mathrm{mM}$ or $10 \mathrm{mM})$, Tris $(0.05 \%)$, Tween $60(0.05 \%)$, and SDS $(0.1 \%)$ in the $0.2 \mathrm{~mL}$ reaction mixture were assayed. The enzyme was incubated with each reagent for $1 \mathrm{~h}$ at $85^{\circ} \mathrm{C}$ before the addition of $p \mathrm{NPX}$ or $p$ NPAF to start the enzyme reaction. The activity of the enzyme without the chemical reagents or metal cations was defined as $100 \%$.

The substrate specificity of the enzyme $(0.1 \mu \mathrm{g})$ was tested by using following substrate, such as $p$-nitrophenyl$\beta$-D-glucopyranoside (Sigma, USA), $p$-nitrophenyl $\alpha$ D-glucopyranoside (Sigma, USA) and linear arabinan (Megazyme International Ireland). Kinetic constant of Tth XynB3 $\beta$-xylosidase was determined by measuring the initial rates at various $p$ NPX or $p$ NPAF ending concentrations $(100,125,150,175,200,250,275,300,325,350$ and $400 \mu \mathrm{M})$ under standard reaction conditions. The influence of various xylose concentrations $(100,200,300,400,500$, 600, 700, 800, 900, 1000, 1100 and $1200 \mathrm{mM}$ ) on the $\beta$-xylosidase activity was investigated. The $K_{i}$ value of xylose was defined as amount of xylose required for inhibiting $50 \%$ of the $\beta$-xylosidase activity and was present as the averages of three separate determinations.

\section{Phylogenies analysis of Tth xynB3 $\beta$-xylosidase}

The potential ORF of Tth $x y n B 3$ was searched using the ORF search tool provided by the National Center for Biotechnology Information (www.ncbi.nlm.nih.gov). Other $54 \beta$-xylosidases amino acid sequences searching were implemented with Blast at NCBI and against CAZy database (www.cazy.org). The multiple sequence alignment tool Clustal X2 was used for sequences alignment [35]. Sequences were further edited and aligned manually by using Mega 5 for editing [36]. Phylogenetic relationships were deduced using the Neighbor-Joining (NJ) and Maximum-Parsimony (MP) methods as performed in Paup 4.0 for the NJ and MP trees. 1000 bootstrap replicates were used for evaluating the trees' topological structure [37]. The trees generated above were displayed using TREEVIEW 1.6.6 (http://taxonomy. zoology.gla. ac.uk/rod/ treeview.html).

\section{Xylooligosaccharides degradation}

The sugar xylobiose, xylotriose and xylotetraose that prepared for $10 \%$ XOs were purchased from Sigma Chemical Co. The XOs were obtained from the cornstalk according to the method as Rémond et al. described [7]. The XOs was treated with purified Tth xynB3 $\beta$-xylosidase, and the degradation was subjected to analysis of thin-layer chromatography (TLC). The reaction mixture $(100 \mu \mathrm{L})$ contained $5 \%$ xylooligosaccharides (wt/vol) and $0.3 \mathrm{U}$ of Tth xynB3 $\beta$-xylosidase in $50 \mathrm{mM}$ imidole-potassium buffer $(\mathrm{pH}$ 6.0). The reaction was carried out for various times $(0.5 \mathrm{~h}, 1 \mathrm{~h}, 2 \mathrm{~h}$ and $3 \mathrm{~h})$ at $75^{\circ} \mathrm{C}$, and stopped by heating for $15 \mathrm{~min}$ in a water bath. After centrifuged for $15 \mathrm{~min}$ at $12,000 \mathrm{rpm}$, the supernatants of the reaction mixtures were applied on silica gel TLC plates (G, Qingdao). Sugars on the plates were separated with a solvent system consisting of $n$-butanol, acetic acid, and water (2:1:1, by vol/vol), and detected using the orcinol/concentrated sulfuric acid reagent [38].

\section{Competing interests}

The authors declare that they have no competing interests.

\section{Authors' contributions}

Hao Shi and Xun Li carried out the cloning and expression and drafted the manuscript. Huaxiang Gu, Yingjuan Huang and Liangliang Wang helped to purified and characterized the Tth xynB3 $\beta$-xylosidase. Yu Zhang and Xun Li helped to revise the manuscript. Fei Wang directed the over-all study and revised the manuscript. All authors read and approved the final manuscript.

\section{Acknowledgements}

This work was financially supported by the National Industry Special Project of China (No. 201004001), the National Natural Science Foundation of China (No. 31170537), Jiangsu Provincial Government (CXZZ11_0526), the Doctorate Fellowship Foundation of Nanjing Forestry University, as well as the Priority Academic Program Development of Jiangsu Higher Education Institutions (PAPD)

Received: 29 November 2012 Accepted: 8 February 2013 Published: 20 February 2013

\section{References}

1. Quintero D, Velasco Z, Hurtado-Gómez E, Neira JL, Contreras LM: Isolation and characterization of a thermostable $\beta$-xylosidase in the thermophilic bacterium Geobacillus pallidus. Biochimica et Biophysica Acta (BBA) Proteins \& Proteomics 2007, 1774(4):510-518.

2. Kambourova M, Mandeva R, Fiume I, Maurelli L, Rossi M, Morana A: Hydrolysis of xylan at high temperature by co-action of the xylanase from Anoxybacillus flavithermus BC and the $\beta$-xylosidase/ $\alpha$-arabinosidase from Sulfolobus solfataricus $\mathrm{O}_{\alpha}$. J Appl Microbiol 2007, 102(6):1586-1593.

3. Morana A, Paris O, Maurelli L, Rossi M, Cannio R: Gene cloning and expression in Escherichia coli of a bi-functional $\beta$-D-xylosidase/a-Larabinosidase from Sulfolobus solfataricus involved in xylan degradation. Extremophiles 2006, 11(1):123-132

4. Kiss T, Erdei A, Kiss L: Investigation of the active site of the extracellular $\beta$-xylosidase from Aspergillus carbonarius. Arch Biochem Biophys 2002, 399(2):188-194.

5. Bokhari SAl, Latif F, Akhtar MW, Rajoka Ml: Characterization of a $\beta$-xylosidase produced by a mutant derivative of Humicola lanuginosa in solid state fermentation. Annals of Microbiology 2010, 60(1):21-29.

6. Ohta K, Fujimoto H, Fuji S, Wakiyama M: Cell-associated $\beta$-xylosidase from Aureobasidium pullulans ATCC 20524: Purification, properties, and characterization of the encoding gene. J Biosci Bioeng 2010, 110(2):152-157.

7. Rémond C, Aubry N, Crônier D, Noël S, Martel F, Roge B, Rakotoarivonina H, Debeire $P$, Chabbert B: Combination of ammonia and xylanase pretreatments: Impact on enzymatic xylan and cellulose recovery from wheat straw. Bioresour Technol 2010, 101(17):6712-6717. 
8. Ohgren K, Bura R, Saddler J, Zacchi G: Effect of hemicellulose and lignin removal on enzymatic hydrolysis of steam pretreated corn stover. Bioresour Technol 2007, 98(13):2503-2510.

9. Zhang J, Siika-aho M, Puranen T, Tang M, Tenkanen M, Viikari L: Thermostable recombinant xylanases from Nonomuraea flexuosa and Thermoascus aurantiacus show distinct properties in the hydrolysis of xylans and pretreated wheat straw. Biotechnol Biofuels 2011, 4(1):12.

10. Katapodis P, Nerinckx W, Claeyssens M, Christakopoulos P: Purification and characterization of a thermostable intracellular $\beta$-xylosidase from the thermophilic fungus Sporotrichum thermophile. Process Biochem 2006, 41(12):2402-2409

11. Pedersen M, Lauritzen HK, Frisvad JC, Meyer AS: Identification of thermostable $\beta$-xylosidase activities produced by Aspergillus brasiliensis and Aspergillus niger. Biotechnol Lett 2007, 29(5):743-748.

12. Ben-David A, Bravman T, Balazs YS, Czjzek M, Schomburg D, Shoham G, Shoham Y: Glycosynthase activity of Geobacillus stearothermophilus GH52 $\beta$-xylosidase: Efficient synthesis of xylooligosaccharides from a-Dxylopyranosyl fluoride through a conjugated reaction. Chembiochem 2007, 8(17):2145-2151.

13. Guerfali M, Maalej I, Gargouri A, Belghith H: Catalytic properties of the immobilized Talaromyces thermophilus $\beta$-xylosidase and its use for xylose and xylooligosaccharides production. J Mol Catal B: Enzym 2009, 57(1-4):242-249.

14. Barker IJ, Petersen L, Reilly PJ: Mechanism of xylobiose hydrolysis by GH43 ß-xylosidase. J Phys Chem B 2010, 114(46):15389-15393.

15. Eneyskaya EV, Ivanen DR, Bobrov KS, Isaeva-Ivanova LS, Shabalin KA, Savel'ev AN, Golubev AM, Kulminskaya AA: Biochemical and kinetic analysis of the GH3 family $\beta$-xylosidase from Aspergillus awamori X-100. Arch Biochem Biophys 2007, 457(2):225-234.

16. Minic Z: Purification and characterization of enzymes exhibiting $\beta$-D-xylosidase activities in stem tissues of arabidopsis. Plant Physiol 2004, 135(2):867-878

17. Shao W, Xue Y, Wu A, Kataeva I, Pei J, Wu H, Wiegel J: Characterization of a novel $\beta$-xylosidase, XyIC, from Thermoanaerobacterium saccharolyticum JW/SL-YS485. Appl Environ Microbio/ 2010, 77(3):719-726.

18. Bravman T: Identification of the catalytic residues in family 52 glycoside hydrolase, a $\beta$-xylosidase from Geobacillus stearothermophilus T-6*. J Biol Chem 2003, 278(29):26742-26749.

19. Windberger $E$, Huber $R$, Trincone A, Fricke H, Stetter KO: Thermotoga thermarum sp.nov and Thermotoga neapolitana ocurring in African continental solfataric springs. Arch Microbiol 1989, 151(6):506-512.

20. Marchler-Bauer A, Lu S, Anderson JB, Chitsaz F, Derbyshire MK, DeWeese-Scott C, Fong JH, Geer LY, Geer RC, Gonzales NR, et al: CDD: a Conserved domain database for the functional annotation of proteins. Nucleic Acids Res 2010, 39(Database):D225-D229.

21. Zanoelo F, Polizeli M, Terenzi H, Jorge J: Purification and biochemical properties of a thermostable xylose-tolerant $\beta$-D-xylosidase from Scytalidium thermophilum. J Ind Microbiol Biotechnol 2004, 31:170-176.

22. Yan QJ, Wang L, Jiang ZQ, Yang SQ, Zhu HF, Li LT: A xylose-tolerant $\beta$-xylosidase from Paecilomyces thermophila: Characterization and its co-action with the endogenous xylanase. Bioresour Technol 2008, 99(13): 5402-5410.

23. Xue $Y M$, Shao WL: Expression and characterization of a thermostable $\beta$-xylosidase from the hyperthermophile, Thermotoga maritima. Biotechnol Lett 2004, 26(19):1511-1515.

24. Zhou J, Bao L, Chang L, Liu Z, You C, Lu H: Beta-xylosidase activity of a $\mathrm{GH} 3$ glucosidase/xylosidase from yak rumen metagenome promotes the enzymatic degradation of hemicellulosic xylans. Lett App/ Microbio/ 2012, 54(2):79-87.

25. Song L, Siguier B, Dumon C, Bozonnet S, O'Donohue MJ: Engineering better biomass-degrading ability into a $\mathrm{GH} 11$ xylanase using a directed evolution strategy. Biotechnol Biofuels 2012, 5(1):3.

26. Zhou J, Bao L, Chang L, Zhou Y, Lu H: Biochemical and kinetic characterization of GH43 $\beta$-D-xylosidase/a-L-arabinofuranosidase and $\mathrm{GH} 30 \mathrm{a}-\mathrm{L}$-arabinofuranosidase/ $\beta-\mathrm{D}$-xylosidase from rumen metagenome. $J$ Ind Microbiol Biotechnol 2011, 39(1):143-152.

27. Smaali I, Rémond C, O'Donohue MJ: Expression in Escherichia coli and characterization of $\beta$-xylosidases $\mathrm{GH} 39$ and $\mathrm{GH}-43$ from Bacillus halodurans C-125. Appl Microbiol Biotechnol 2006, 73(3):582-590.

28. Ghosh M, Das A, Mishra AK, Nanda G: Aspergillus sydowii MG-49 is a strong producer of thermostable xylanolytic enzymes. Enzyme Microb Technol 1993, 15(8):703-709.
29. Hebraud M, Fevre M: Purification and charaterization of an glycoside hydrolase from the anaerobic ruminal fungus Neocallimastix frontalis. Appl Environ Microbiol 1990, 56(10):3164-3169.

30. Pei JJ, Pang Q, Zhao LG, Fan S, Shi H: Thermoanaerobacterium thermosaccharolyticum $\beta$-glucosidase: a glucose-tolerant enzyme with high specific activity for cellobiose. Biotechnol Biofuels 2012, 5

31. Han $Y$, Chen $H: A \beta$-xylosidase from cell wall of maize: Purification, properties and its use in hydrolysis of plant cell wall. $J$ Mol Catal B: Enzym 2010, 63(3-4):135-140.

32. Xiong JS, Balland-Vanney $M$, Xie ZP, Schultze $M$, Kondorosi A, Kondorosi $E_{,}$ Staehelin C: Molecular cloning of a bifunctional $\beta$-xylosidase/a-Larabinosidase from alfalfa roots: heterologous expression in Medicago truncatula and substrate specificity of the purified enzyme. J Exp Bot 2007, 58(11):2799-2810.

33. Laemmli UK: Cleavage of structural proteins during the assembly of the head of bacteriophage T4. Nature 1970, 227(5259):680-685.

34. Zhang Y, Raudah S, Teo H, Teo GWS, Fan R, Sun X, Orner BP: Alanineshaving mutagenesis to determine key interfacial residues governing the assembly of a nano-cage maxi-ferritin. J Biol Chem 2010, 285(16): 12078-12086

35. Larkin MA, Blackshields G, Brown NP, Chenna R, McGettigan PA, McWilliam H, Valentin F, Wallace IM, Wilm A, Lopez R, et al: Clustal W and clustal X version 2.0. Bioinformatics 2007, 23(21):2947-2948

36. Tamura K, Peterson D, Peterson N, Stecher G, Nei M, Kumar S: MEGA5: Molecular evolutionary genetics analysis using maximum likelihood, evolutionary distance, and maximum parsimony methods. Mol Biol Evol 2011, 28(10):2731-2739.

37. Wilgenbusch JC, Swofford D: Inferring evolutionary trees with PAUP*. Current protocols in bioinformatics / editoral board, Andreas D Baxevanis [et al.] 2003, Chaper 6, unit 6.4. http://www.currentprotocols.com/protocol/bi0604.

38. Okuyama M, Okuno A, Shimizu N, Mori H, Kimura A, Chiba S: Carboxyl group of residue Asp647 as possible proton donor in catalytic reaction of alpha-glucosidase from Schizosaccharomyces pombe. Eur J Biochem 2001, 268(8):2270-2280.

doi:10.1186/1754-6834-6-27

Cite this article as: Shi et al:: Biochemical properties of a novel thermostable and highly xylose-tolerant $\beta$-xylosidase/ $a$-arabinosidase from Thermotoga thermarum. Biotechnology for Biofuels 2013 6:27.

\section{Submit your next manuscript to BioMed Central and take full advantage of:}

- Convenient online submission

- Thorough peer review

- No space constraints or color figure charges

- Immediate publication on acceptance

- Inclusion in PubMed, CAS, Scopus and Google Scholar

- Research which is freely available for redistribution 